\title{
First photographic evidence of the iconic big mammals of Honduras, Baird's Tapir (Tapirus bairdii) and Jaguar (Panthera onca), in La Muralla Wildlife Refuge
}

\author{
KeVin O. Sagastume-Espinoza ${ }^{1}{ }^{2 *}$ and Saulo J. Romero ${ }^{1,2}$ \\ ${ }^{1}$ Laboratorios de Zoología, Escuela de Biología, Universidad Nacional Autónoma de Honduras, Blvd. Suyapa, Ciudad Universitaria, \\ Tegucigalpa. Francisco Morazán, Honduras. Email: kose998@hotmail.com (KOSE). \\ ${ }^{2}$ Departamento de Biología, Escuela de Biología, Universidad Nacional Autónoma de Honduras, Blvd. Suyapa, Ciudad Universitaria, \\ Tegucigalpa. Francisco Morazán, Honduras. Email: shauli74@yahoo.com (SJRG). \\ * Corresponding author
}

In Honduras, the biggest land mammals found are the Baird's tapir and the jaguar. Both species have been documented previously for La Muralla Wildlife Refuge, Olancho, Honduras, but there has never been photographic evidence of their presence. In the present, we show the first photographic evidence for both species captured using camera-traps during a one month period. With this evidence new conservation efforts can be planned taking in consideration the recent presence of both iconic species in the refuge and the country as well as an important connectivity spot for the species populations.

En Honduras, los mamíferos terrestres más grandes son el tapir de Baird y el jaguar. Ambas especies han sido documentadas previamente para El Refugio de Vida Silvestre La Muralla, Olancho, Honduras, pero no había sido presentada una evidencia fotográfica de su presencia. En el presente, mostramos los primeros registros fotográficos para ambas especies capturadas mediante trampas cámara en el periodo de un mes de trabajo. Con estas nuevas evidencias se pueden desarrollar esfuerzos de conservación que tomen en consideración la presencia reciente de ambas especies icónicas para el refugio y el país en general, así como un punto de conectividad importante para las poblaciones de ambas especies.

Key words: camera traps; connectivity spot; Honduras.

C 2017 Asociación Mexicana de Mastozoología, www.mastozoologiamexicana.org

\section{Introduction}

Possibly the two most iconic species of land mammals that anyone can find in Honduras and Central America are the Baird's tapir (Tapirus bairdii) and the jaguar (Panthera onca). Both species were historically distributed in most of Honduran territory, but due to habitat loss, forest fragmentation, and hunting pressures they can only be found in some forest remnants in the western parts (La Mosktia and Patuca region) and the north coast, Nombre de Dios and Merendón mountain ranges (ICF 2011a; ICF 2011b) of Honduras.

The distribution of both species in the country's central part lacks of evidence of their presence. Occurrence of the tapir was reported for the Agalta and Carbon mountain ranges in the departments of Olancho and Colon (Flesher 1999; Estrada 2004), and it has been widely found in the Moskitia Biosphere region according to studies by different authors (Estrada 2006; Castañeda 2009; Hernandez and Portillo 2008; Townsend 2002b). It has also been reported from Cusuco National Park, in the east mountain ranges of Merendón (Operation Wallacea 2006). The distribution of the jaguar is similar, it has been reported several times for the Moskitia Biosphere (Cruz 2001; Castañeda 2009; Polisar et al. 2009; Portillo et al. 2008). For the north coast there have been several reports for Pico Bonito National Park and Jeannette Kawas National Park (Castañeda et al. 2011a; 2011b).

There have been studies with camera traps conducted inside La Muralla Wildlife Refuge with no photographic results of either species (Moreno 2012; Portillo and Elvir 2013a; Portillo and Elvir 2013b). Portillo and Elvir (2013a) conducted a study of cats (Felidae) in protected areas in Honduras, in which one of the study sites was La Muralla Wildlife Refuge. In that study they found three species of cats, puma (Puma concolor), ocelot (Leopardus pardalis), and margay (L. wiedii), but they do not mention any evidence about the presence of jaguar. Moreno (2012) reports the presence of tapir in the refuge based on a footprint found in one of the trials, but failed to provide a photographic proof of the species. In the same document, the author reports puma (Puma concolor) as the biggest cat in the park, but did not find any evidence whatsoever of jaguar in the refuge. The Centro de Estudios Ambientales de Honduras $(\mathrm{CEAH} ; 2010)$ elaborated the management plan for the refuge, but were unsure about the presence of jaguar. They also report the presence of tapir, and provide the picture of a tapir's skull that is shown in the visitor center, but fail to provide further information like the exact place and date where it was found. Portillo and Elvir (2013b) report the presence of tapir in La Muralla Wildlife Refuge based on a study using camera traps; nevertheless, Portillo (2016, pers. comm.) states that the evidence comes from Moreno's (2012) footprint previous report, meaning that there is still no camera-trap evidence for the species. Here we present the first photographic evidence for tapir and jaguar from La Muralla Wildlife Refuge, Olancho, Honduras. 


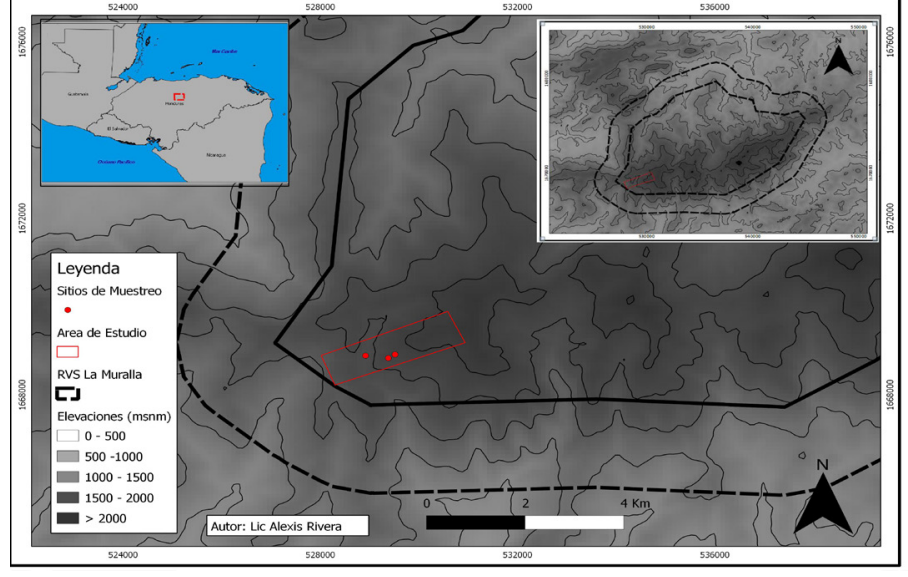

Figure 1. Location of Camera Traps in La Muralla Wildlife Refuge.

\section{Materials and Methods}

La Muralla Wildlife Refuge is a protected area in the Olancho Department in the northeastern region of Honduras. It has an extension of 26,903 hectares and forms part of the Agalta Mountain range. The mayor part of the Refuge is covered by broad leaf forest, having a mean temperature between 12 to $18^{\circ} \mathrm{C}$. It has fragmented landscapes used mainly for agricultural activities. The forest plot where the cameras where set corresponds to a primary tropical cloud forest with a mature vegetation and trees with over 35 meters height, with dominant species like Brosimum alicatrum (Masica), Calatola costarisensis (Nogal), Nectandra sp. (Rosita), and Persea sp., and a forest floor covered mostly by grass.

For a brief survey conducted in La Muralla Wildlife Refuge we set three camera traps (Browning Strike Force BTC5-Browning Trial Cameras, U. S. A) along the "Monte Escondido" trial on the $8^{\text {th }}$ of August 2015 (Figure 1). The camera traps where then recollected the $13^{\text {th }}$ of September which sums a total of 36 nights/camera. All the cameras where set next to the trial and programed for pictures only.

\section{Results}

A total of 164 pictures where obtained from the three cameras, 30 of those were of one tapir in a single event (Captured on T2, 25 August $\left.2015,6: 06 \mathrm{pm} ; 15.094903^{\circ},-86.726429^{\circ}\right)$, this repre- sents the $18.3 \%$ of the total. Five pictures were of one jaguar in a single event (Captured on T3, 9 September 2015, 3:33 am; $\left.15.095643^{\circ},-86.725163^{\circ}\right)$, which represents the $3.05 \%$. Based on these images we could determine that the specimen of tapir is an adult male and the jaguar is an adult of unknown sex (Figure 2).

\section{Discussion}

The presence of these two species in La Muralla Wildlife Refuge, as well as other interesting species such as ocelot (Leopardus pardalis), margay (L. wiedii), and agoutis (Cuniculus paca), is an indicative of the good state of conservation of the refuge. It is known that tapirs inhabit habitats with low to none human intervention because they need areas that will serve as foraging places, with enough food availability and big spaces providing resources for their wellbeing. The scenario for the jaguar is basically the same, with the difference that it has been proved that they can coexist closer to humans, evidence of this is the cattle conflict there has been going on for years all over the Americas. Nevertheless, the habitat in Honduras has been so fragmented and areas deforested to the point that both species are now limited to the high and isolated parts of protected areas where human intervention is less noticeable, or in the wide savannas of the Moskitia region.

The Muralla Wildlife Refuge is a remarkable spot for both the tapir and jaguar connectivity because of the geographic position it has in the country. This is why this report is important in order to consider La Muralla as a connectivity area among populations throughout the different protected areas in the country. Even though Flesher (1999) and Estrada (2004) confirmed the presence of tapirs for the Agalta range, this report, along with Moreno's footprint (2012), can be considered the most relevant record for the species at the Refuge. Considering the Initiative for the Jaguar Corridor in Honduras (Panthera 2014a) and the actual present range reported by Panthera (2014b), it is clear the importance of jaguar's presence at the refuge which is serving as a connectivity spot along the country. La Muralla Wildlife Refuge must be considered a key place for conservation and management plans to protect this two endangered species.

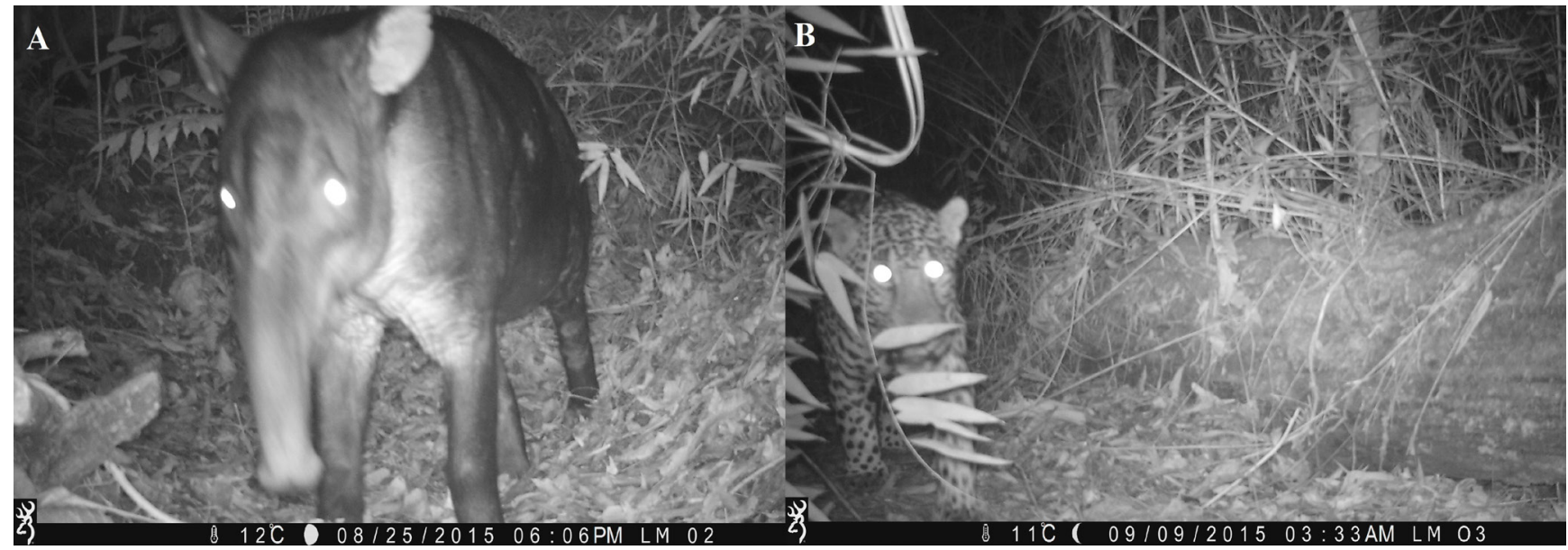

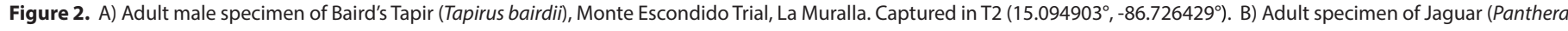
onca), Monte Escondido Trial, La Muralla. Captured in T3 $\left(15.095643^{\circ},-86.725163^{\circ}\right)$. 


\section{Acknowledgments}

We thank RETE/MOSEF for providing financial assistance and equipment for the field trip, to Fundación PANAM and Escuela de Biología-UNAH for helping with logistics and permits. We also thank N. Estrada for her help with preparing this manuscript and for valuable comments on the same. G. Sandoval kindly provided the forest description of where cameras were mounted and A. Rivera helped with the elaboration of the map. To A. Matute, J. J. Cruz, O. Amador, and V. Henriquez for helping with the survey conducted at La Muralla that resulted in this and other important findings. We thank R. Reyna, S. T. Alvarez, H. Portillo and an anonymous reviser for their comments and corrections to the manuscript.

\section{Literature cited}

CAstañedA, F. 2009. Datos preliminares sobre la distribución del jaguar (Panthera onca), el estado de sus especie presa, y el conflicto felinos-ganadería en la Moskitia Hondureña. Wildlife Conservation Society, Tegucigalpa, Honduras.

Castañeda, F., S. Pereira, And M. Solís. 2011a. In the middle of the corridor: status of Panthera onca at Pico Bonito National Park, Honduras. Revista Mesoamericana 15:73.

Castañeda, F., L. Herrera, S. Pereira, and D. Sierra. $2011 \mathrm{~b}$. Estado del jaguar (Panthera onca) en el Parque Nacional Jeannette Kawas, Honduras. Panthera, Prolansate, Instituto Conservación y Desarrollo Forestal, Áreas Protegidas y Vida Silvestre. Tegucigalpa, Honduras.

Centro de Estudios Ambientales de Honduras. 2010. Plan de Manejo Refugio de Vida Silvestre La Muralla 2011-2015. Instituto Nacional de Conservación y Desarrollo Forestal, Áreas Protegidas y Vida Silvestre- Departamento de Áreas Protegidas (DAP). Tegucigalpa, Honduras.

CRUZ, G. 2001. Preliminary results on cat-cattle conflicts in Brus Laguna, La Moskitia. WCS. In: Instituto Nacional Conservación y Desarrollo Forestal, Áreas Protegidas y Vida Silvestre. 2011b. Plan Nacional para la Conservación del Jaguar (Panthera onca); Promoviendo la convivencia ComunidadJaguar. Departamento de Vida Silvestre/ Instituto Nacional de Conservación y Desarrollo Forestal, Áreas Protegidas y Vida Silvestre- Proyecto Ecosistemas-Fundación Panthera. Tegucigalpa, Honduras.

EstRADA, N. 2004. Notes on the relative abundance and hunting of baird's tapir in the Rus-Rus region of la moskitia, Honduras: a proposed biological reserve. Tapir Conservation 13:28-29

Estrada, N. 2006. Ecología del Danto (Tapirus bairdii) en el Parque Nacional Sierra de Agalta, Olancho, Honduras. Proyecto USAID/MIRA. Tegucigalpa, Honduras.

FLESHER, K. 1999. Preliminary notes on the conservation status of Baird's tapir Tapirus bairdii in north-eastern Honduras. Oryx 33:294-300

HeRnández, J., AND H. Portillo. 2008. Abundancia relativa de tapir en Rus Rus, Honduras, 3p, in ICF. 2011 a. Plan Nacional para la Conservación del Danto (Tapirus bairdii), N. Estrada, S. Bonilla y J. Mora. Departamento de Vida Silvestre/ Instituto Nacional de Conservación y Desarrollo Forestal, Áreas Protegidas y Vida Silvestre-Proyecto Ecosistemas-Grupo de Especialistas de Tapires SSC-UICN. Tegucigalpa, Honduras.
Instituto Nacional de Conservación y Desarrollo Forestal, Áreas Protegidas y Vida Silvestre. 2011a. Plan Nacional para la Conservación del Danto (Tapirus bairdii). Departamento de Vida Silvestre/ Instituto Nacional de Conservación y Desarrollo Forestal, Áreas Protegidas y Vida SilvestreProyecto Ecosistemas-Grupo de Especialistas de Tapires SSCUICN. Tegucigalpa, Honduras.

instituto Nacional de Conservación y Desarrollo Forestal, Áreas Protegidas y VIDA Silvestre. 2011b. Plan Nacional para la Conservación del Jaguar (Panthera onca); Promoviendo la convivencia Comunidad-Jaguar. Departamento de Vida Silvestre/ Instituto Nacional de Conservación y Desarrollo Forestal, Áreas Protegidas y Vida Silvestre- Proyecto Ecosistemas-Fundación Panthera. Tegucigalpa, Honduras.

Operation Wallacea. 2006. Baird's tapir monitoring. In: Field Report: University of Nottingham/ Operation Wallacea Forest Projects, Honduras 2006. Nottingham, United Kingdom. Retrieved from: https://opwall.com/wp-content/uploads/ Cusuco-Field-Report-2006.pdf

Panthera. 2014a. La Iniciativa del Corredor del Jaguar; creando un paso seguro para los Jaguares en el Presente y hacia el Futuro. Panthera. New York, U. S. A. Retrieved from: https:// www.panthera.org/initiative/jaguar-corridor-initiative

PANTHERA. 2014b. Jaguar's Historic and Current Range. Panthera. New York, U. S. A. Retrieved from: https://www.panthera. $\mathrm{org} / \mathrm{cms} / \mathrm{sites} /$ default/files/Jaguar Current and Historic Range Feb 2014 HSR 0.pdf

Polisar, J., J. Mora, F. CastañedA, And L. I. López. 2009. Talleres de Manejo de Fincas Ganaderas y Conservación de Jaguar (Panthera onca) en los Valles y Llanos de La Mosquitia Hondureña. Reporte técnico para Wildlife Conservation Society. Tegucigalpa, Honduras.

Portillo, H., T. Manzanares, T. Manzanares, JR., S. Lacut, and R. Lacut. 2008. Estimating Jaguar Population Using Traps Camera in One Hundred Square Kilometers in Rus Rus La Mosquitia, Honduras. Wildlife Conservation Society. Tegucigalpa, Honduras.

MoReno, R. 2012. Primer Informe Inventariado de Integridad Ecológica Realizada para el Refugio de Vida Silvestre La Muralla. Fundación PANAM. La Unión, Honduras.

PorTILLO, H., AND F. ElVIR. 2013a. Distribución de Felinos Silvestres en Áreas Protegidas de Honduras. Revista Mexicana de Mastozoología. 3:26-35

Portillo, H., AND F. Elvir. 2013b. Composición, Estructura y Diversidad de Mamíferos Terrestres Grandes y Medianos en 16 Áreas Protegidas en Honduras, Usando fotocapturas como Evidencia de Registro. Mesoamericana 17:15-29

ToWNSEND, J. 2002b. Notes on the Baird's Tapir (Tapirus bairdii) from the southern region of Biosfera Tawahka-Asagni, Honduras. Tapir Conservation 11:16-17

Associated editor: Rafael Reyna

Submitted: October 19, 2016; Reviewed: November 30, 2016;

Accepted: December 19, 2016; Published on line January 12, 2017. 
66 THERYA Vol. 8(1): $63-65$ 